\title{
TIME-TEMPERATURE-TRANSFORMATION DIAGRAM OF ALLOY 945
}

\author{
Sarwan Mannan \\ Special Metals Corporation \\ 3200, Riverside Drive, Huntington, WV 25705
}

Keywords: Alloy 945, Metallographic analysis, Phase stability

\begin{abstract}
Commercially produced INCOLOY ${ }^{\circledR}$ alloy 945 was annealed and heat-treated in the temperature range of $650^{\circ} \mathrm{C}$ to $982^{\circ} \mathrm{C}$ for the times of 15 minutes to 100 hours. Heat-treated specimens were tested for hardness, optical metallography, scanning electron microscopy (SEM), energy dispersive $\mathrm{x}$-ray (EDX) analysis of bulk and electrolytically extracted residue, $\mathrm{x}$-ray diffraction (XRD) of the residue and transmission electron microscopy (TEM) to develop understanding for phase stability. Data generated from these analytical techniques is presented in the form of a time-temperature-transformation diagram (TTT).
\end{abstract}

\section{Introduction}

Alloy 945 of nominal composition Fe-47Ni-20.5Cr-3Mo-2Cu-3Nb-1.5Ti is specially designed for oil and gas $(\mathrm{O} \& \mathrm{G})$ applications. High $\mathrm{Cr}$ content and alloying with $\mathrm{Mo}$ and $\mathrm{Cu}$ makes it suitable for corrosive O\&G environments which generally contain high level of chloride, $\mathrm{H}_{2} \mathrm{~S}$, and $\mathrm{CO}_{2}$ at high temperature low $\mathrm{pH}$ acidic conditions with or without $\mathrm{S}[1,2] . \mathrm{Nb}$ and $\mathrm{Ti}$ contents result in precipitation of intermetallic phases $\gamma^{\prime \prime} \mathrm{Ni}_{3}(\mathrm{NbAlTi})$, and $\gamma^{\prime} \mathrm{Ni}_{3}$ (AlTi) [3], which are responsible for the high strength required for deep water exploration and production.

Mechanical properties and $O \& G$ corrosion resistance are governed by the microstructure $[4,5]$. Therefore, the O\&G industry has come up with rather stringent microstructure requirements [6]. To tailor the microstructure for properties, an understanding of phase stability with time and temperature is essential. In this study, commercially produced material was annealed at $1038^{\circ} \mathrm{C}$ for 1 hour and heat-treated in the temperature range of $650^{\circ} \mathrm{C}$ to $982^{\circ} \mathrm{C}$ for the times of 15 minutes to 100 hours. This was followed by hardness testing, optical metallography, SEM/EDX analysis of bulk and electrolytically extracted residue, XRD and TEM analysis. Data generated using these analytical techniques are presented in the form of a TTT diagram.

\section{Experimental Procedure}

A commercial heat of alloy 945 was vacuum induction melted to $460 \mathrm{~mm}$ diameter and vacuum arc re-melted to $500 \mathrm{~mm}$ diameter. This was followed by metal working down to $90 \mathrm{~mm}$ diameter. Then, the material was annealed and aged using recommended time-temperature conditions. Material satisfied microstructural requirements and minimum specified mechanical properties. 
( INCOLOY is a trademark of Special Metal Corporation, a PCC company.

Specimens were cut from this rod, annealed in the lab at $1038^{\circ} \mathrm{C}$ for 1 hour, and water quenched. Annealed specimens were heat-treated in the temperature range of $649^{\circ} \mathrm{C}$ to $982^{\circ} \mathrm{C}$ for the times of 15 minutes to 100 hours and tested for microstructure and hardness. Analyzed chemical composition of the material is given in Table I.

Table I. Chemical Composition (wt \%)

\begin{tabular}{|c|c|c|c|c|c|c|c|c|c|c|}
\hline $\mathrm{Ni}$ & $\mathrm{Fe}$ & $\mathrm{Cr}$ & $\mathrm{Mo}$ & $\mathrm{Nb}$ & $\mathrm{Cu}$ & $\mathrm{Ti}$ & $\mathrm{Al}$ & $\mathrm{C}$ & $\mathrm{Mn}$ & $\mathrm{S}$ \\
\hline 47.1 & 22.4 & 20.5 & 3.2 & 3.1 & 2.0 & 1.49 & 0.20 & 0.011 & 0.07 & 0.0004 \\
\hline
\end{tabular}

\section{Optical Metallography and Scanning Electron Microscopy}

Swab etching using Seven acid's etchant containing $300 \mathrm{ml}$ hydrochloric acid, $60 \mathrm{ml}$ nitric acid, $30 \mathrm{ml} \mathrm{40 \%} \mathrm{hydrofluoric} \mathrm{acids,} 30 \mathrm{ml}$ sulfuric acid, $30 \mathrm{gm}$ anhydrous ferric chloride, $60 \mathrm{ml}$ acetic acid and $300 \mathrm{ml}$ water was found to be suitable to reveal the microstructure. Polished specimens were subjected to electrolytic extraction in $\mathrm{CH}_{3} \mathrm{OH} / \mathrm{HCl}$ at $0.5 \mathrm{~A}$ for $4-20$ hours using standard ASTM practice E963-83. The extracted residue was subjected to SEM/EDX and XRD analyses.

\section{Transmission Electron Microscopy}

To prepare specimens for TEM, 400-500 $\mu \mathrm{m}$ thick foils were cut with a precision saw. The $3 \mathrm{~mm}$ discs were mechanically punched from the foils and ground to $150-200 \mu \mathrm{m}$. The discs were then electrolytically polished by a twin jet thinning apparatus using a solution of $10 \%$ perchloric acid in methanol at $28 \mathrm{~V}$ and at $-50^{\circ} \mathrm{C}$. Thin foils were examined with a Phillips EM 400 microscope.

\section{Results and Discussion}

\section{Time Temperature Hardness}

The hardness was determined on Rockwell B and C scales and converted to Vickers Hardness Numbers (VHN) using ASTM practice E 140-05. Table II shows the hardness of the specimens annealed at $1038^{\circ} \mathrm{C}$, water quenched and exposed in the temperature range of $649^{\circ} \mathrm{C}$ to $982^{\circ} \mathrm{C}$ for the time of 15 minutes to 100 hours. Time-Temperature-Hardness (TTH) plot is shown in figure 1. The hardness of annealed material was $160 \mathrm{VHN}$. Precipitation hardening zones for $250 \mathrm{VHN}$ and $300 \mathrm{VHN}$ are revealed in Figure 1. Strengthening potency is highest in the temperature range of $649^{\circ} \mathrm{C}$ to $760^{\circ} \mathrm{C}$.

Table II. Vickers hardness numbers of the material annealed at $1038^{\circ} \mathrm{C}$, water quenched and exposed at the listed time temperatures. The hardness of annealed material was $160 \mathrm{VHN}$.

\begin{tabular}{|c|c|c|c|c|c|c|c|c|}
\hline Temperature & $0.25 \mathrm{~h}$ & $0.50 \mathrm{~h}$ & $1 \mathrm{~h}$ & $4 \mathrm{~h}$ & $8 \mathrm{~h}$ & $25 \mathrm{~h}$ & $50 \mathrm{~h}$ & $100 \mathrm{~h}$ \\
\hline $649^{\circ} \mathrm{C}$ & - & - & 199 & - & 240 & 264 & 297 & 345 \\
\hline $705^{\circ} \mathrm{C}$ & - & - & 249 & - & 331 & 358 & 348 & 364 \\
\hline $760^{\circ} \mathrm{C}$ & 276 & 287 & - & 327 & 325 & 306 & - & 310 \\
\hline $816^{\circ} \mathrm{C}$ & 266 & 275 & - & 272 & 268 & - & - & - \\
\hline $871^{\circ} \mathrm{C}$ & 181 & 184 & - & 188 & 195 & - & 186 & 188 \\
\hline $927^{\circ} \mathrm{C}$ & & & & & 154 & 148 & & \\
\hline $955^{\circ} \mathrm{C}$ & 161 & 162 & - & 155 & 158 & 165 & - & 164 \\
\hline $982^{\circ} \mathrm{C}$ & 163 & 155 & - & 158 & 160 & 161 & - & 151 \\
\hline
\end{tabular}




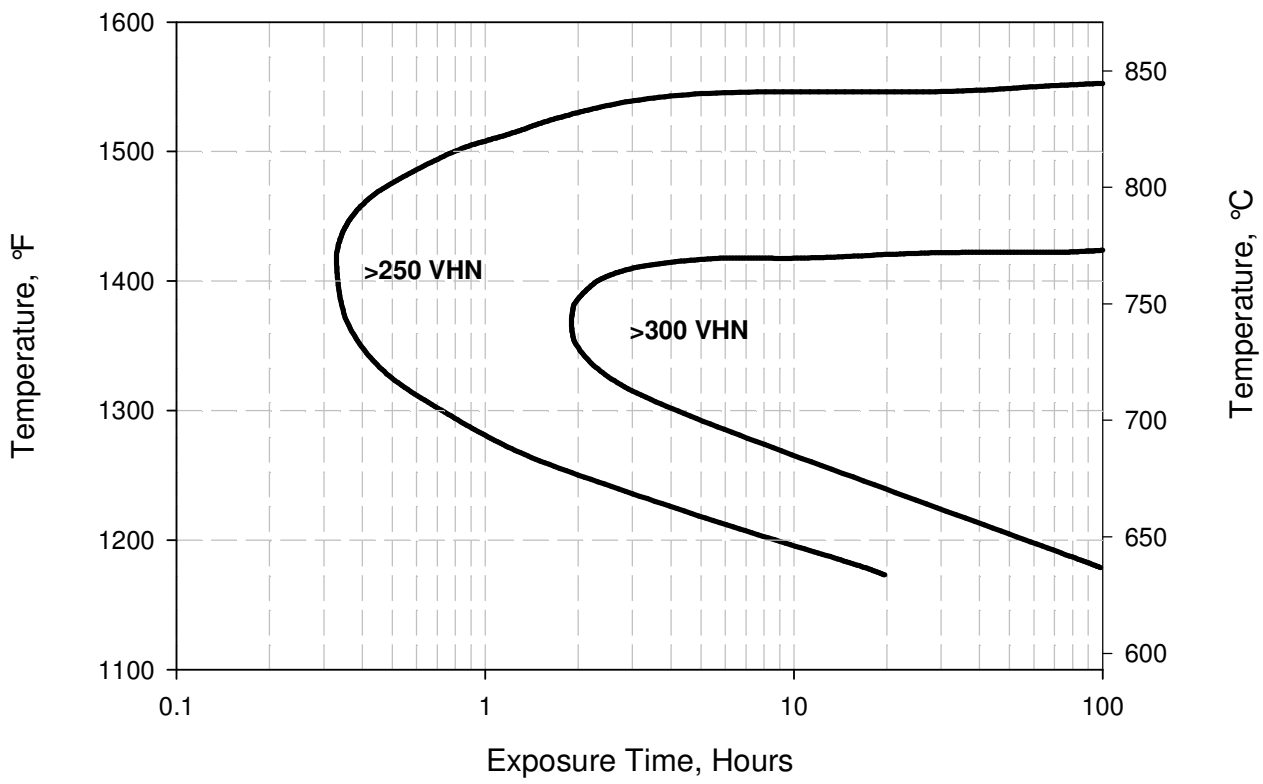

Figure 1. Time Temperature Hardness plot of material annealed at $1038^{\circ} \mathrm{C}$ for $1 \mathrm{~h}$ and water quenched prior to the heat treatments. The hardness of annealed material was $160 \mathrm{VHN}$.

\section{Microstructure at $649^{\circ} \mathrm{C}, 704^{\circ} \mathrm{C}$ and $760^{\circ} \mathrm{C}$}

Gamma prime and gamma double prime are formed at these temperatures in times as short as 1 hour as can be inferred from the hardness increase. Short time exposure at $649^{\circ} \mathrm{C}$ results in microstructure which is essentially devoid of inter-granular precipitates, figure 2a. However, prolonged exposures at $649^{\circ} \mathrm{C}$ and $704^{\circ} \mathrm{C}$ result in inter-granular precipitates as shown in figure $2 \mathrm{~b}$. These precipitates were identified as $\mathrm{M}_{23} \mathrm{C}_{6}$-type carbides. Figure $2 \mathrm{~b}$ also shows a fine circled spherical particle, which was identified as Nb-rich by EDX analysis and is presumably $\mathrm{NbC}$. These $\mathrm{NbC}$ precipitates are present in all the analyzed samples. These precipitates are formed primarily on thermo-mechanical processing. Longer exposures at $760^{\circ} \mathrm{C}$ results in heavy intergranular $\mathrm{M}_{23} \mathrm{C}_{6}$ carbides and $\mathrm{Ni}_{3}$ Ti-type $\eta$ as shown in figure $3 \mathrm{a}$ and $3 \mathrm{~b}$. Analytical analysis of these precipitates will be presented later in the text.

\section{Microstructure at $816^{\circ} \mathrm{C}$ and $871^{\circ} \mathrm{C}$}

This temperature range is the busiest zone for formation of various phases. Phase formation at both these temperatures is similar. Due to higher kinetics at higher temperature, volume fraction and sizes of these precipitates is larger in the samples exposed at $871^{\circ} \mathrm{C}$, which makes it easier to do analytical work on these samples. Therefore extensive analysis is shown for a sample exposed at $871^{\circ} \mathrm{C}$ for $100 \mathrm{~h}$. It should be mentioned that these microstructures are purely for academic information and have no practical utility since alloy 945 is not recommended for use at $816^{\circ} \mathrm{C}$ and $871^{\circ} \mathrm{C}$. Figures $4 \mathrm{a}$ and $4 \mathrm{~b}$ reveal coarsened $\gamma^{\prime} / \gamma^{\prime \prime}$ particles and inter- and intra-granular $\eta$ phase colonies in the sample exposed at $871^{\circ} \mathrm{C}$ for $100 \mathrm{~h}$. Precipitate free zones (PFZ) adjacent to grain boundaries and $\eta$ particles are also shown.

The data in table II and figure 1 suggest that $\gamma^{\prime} / \gamma^{\prime \prime}$ precipitates could be in solution at $871^{\circ} \mathrm{C}$ since only negligible hardening is observed on exposure at this temperature. From data presented in figures 1 and 4, it can be inferred that although $\gamma / \gamma^{\prime \prime}$ precipitates are sill present on exposure at $871^{\circ} \mathrm{C}$ for $100 \mathrm{~h}$, these are ineffective for any significant hardening. 
Figures $5 \mathrm{a}$ and $5 \mathrm{~b}$ show two morphologically different inter-granular precipitates, thin elongated and roundish irregular respectively, shown by circles. The circle is about 3 micron diameter, which is the approximate spatial resolution of an electron beam for EDX detection [7]. Figure 5c and $5 \mathrm{~d}$ show that precipitates revealed in figures $5 \mathrm{a}$ and $5 \mathrm{~b}$ are enriched in $\mathrm{Cr}$ and $\mathrm{Cr}+\mathrm{Ni}+\mathrm{Fe}$ respectively. Since these particles are smaller than the spatial resolution of an electron beam, the surrounding matrix and $\eta$ particles are picked up in EDX analysis resulting in erroneous relative elemental concentration. To eliminate these errors, the sample was electrolytically dissolved and individual particles from the extracted residue were placed on a carbon stub for EDX analysis. Figure $6 \mathrm{a}$ and $6 \mathrm{~b}$ show elongated and irregular-roundish particles. The EDX patterns of these individual particles shown in figures $6 \mathrm{a}$ and $6 \mathrm{~b}$ matched with the EDX patterns shown in figures $5 \mathrm{c}$ and $5 \mathrm{~d}$ respectively. Previous observations suggest that these 1-2 micron diameter intergranular precipitates in alloy 945 can be conclusively identified for relative concentration using SEM/EDX analysis of bulk samples, whereas unambiguous identification of 0.25 to 0.5 micron or smaller inter-granular particles was not possible in bulk samples. Electrolytic extraction process was required for conclusive identification of these smaller particles.
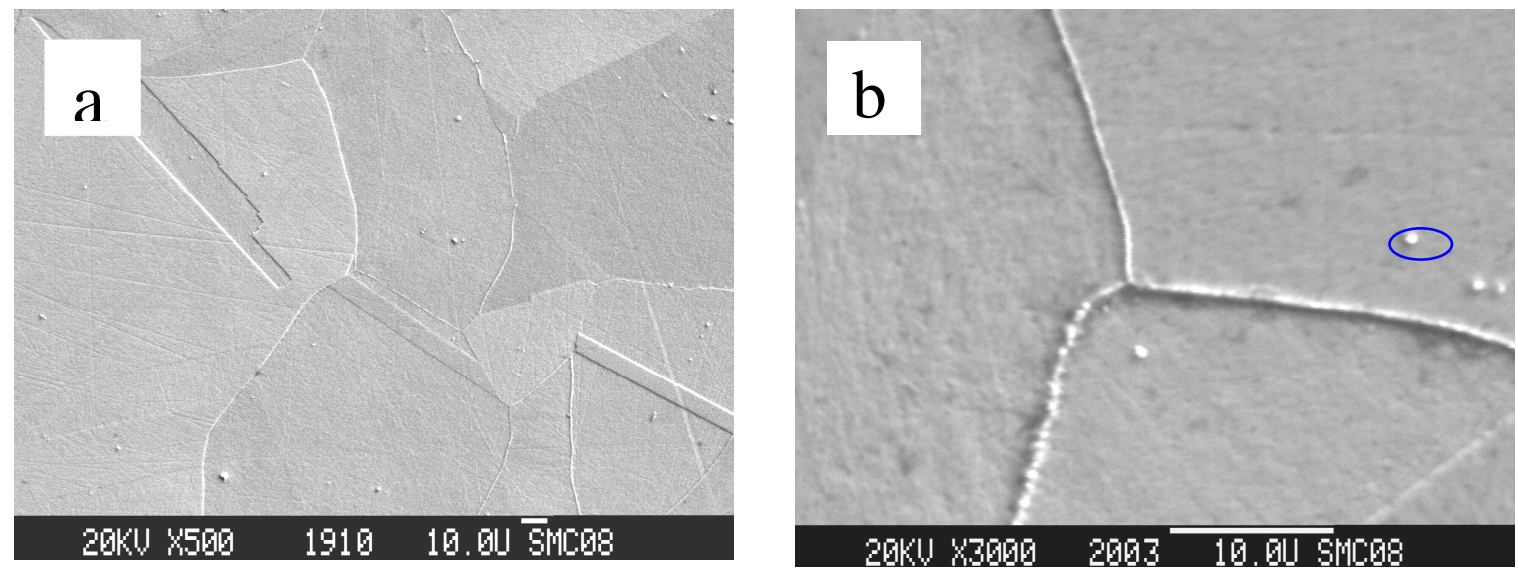

Figure 2. a) SEM photograph of sample exposed at $649^{\circ} \mathrm{C}$ for $1 \mathrm{~h}$ showing a microstructure essentially devoid of inter-granular precipitation. b) SEM photographs of a sample exposed at $704^{\circ} \mathrm{C}$ for $25 \mathrm{~h}$ showing $\mathrm{M}_{23} \mathrm{C}_{6}$-type carbides. The circled fine spherical precipitate in figure $2 \mathrm{~b}$ is $\mathrm{NbC}$.
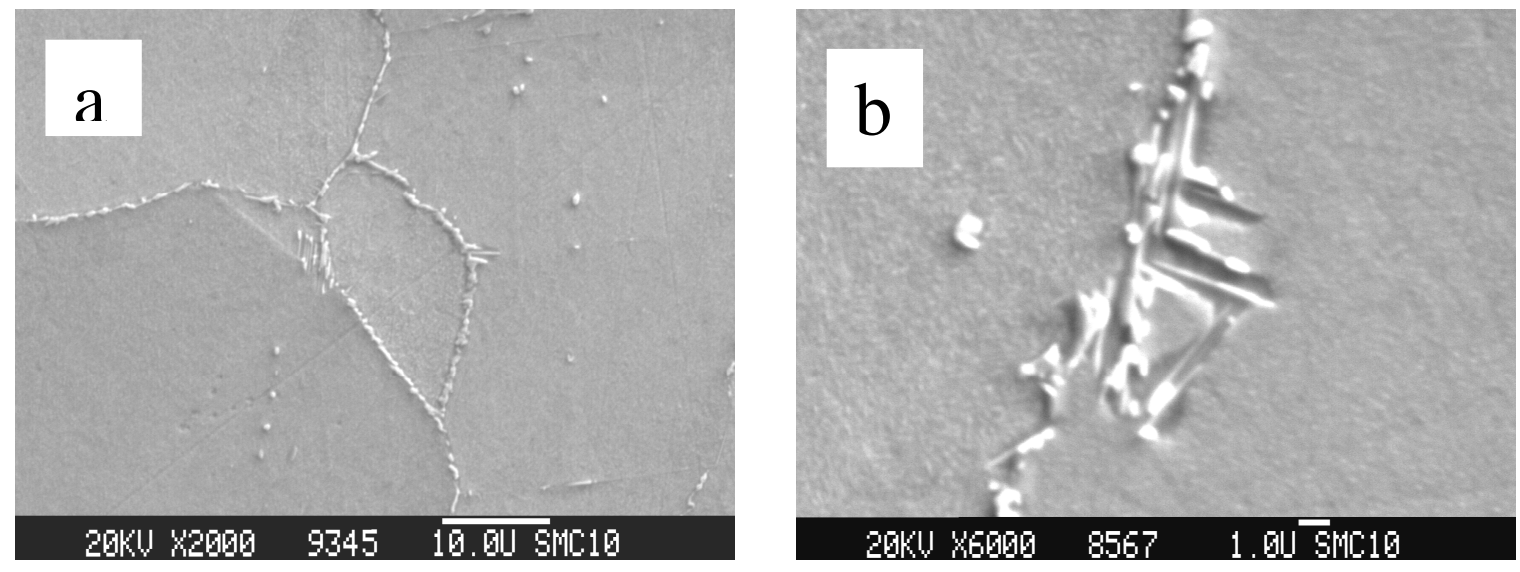
Figures $3 \mathrm{a}$ and $3 \mathrm{~b}$ show $\mathrm{M}_{23} \mathrm{C}_{6}$ carbide and $\eta$ phase precipitates. Acicular morphology of $\eta$ phase is clearly shown at higher magnification in figure $3 \mathrm{~b}$.
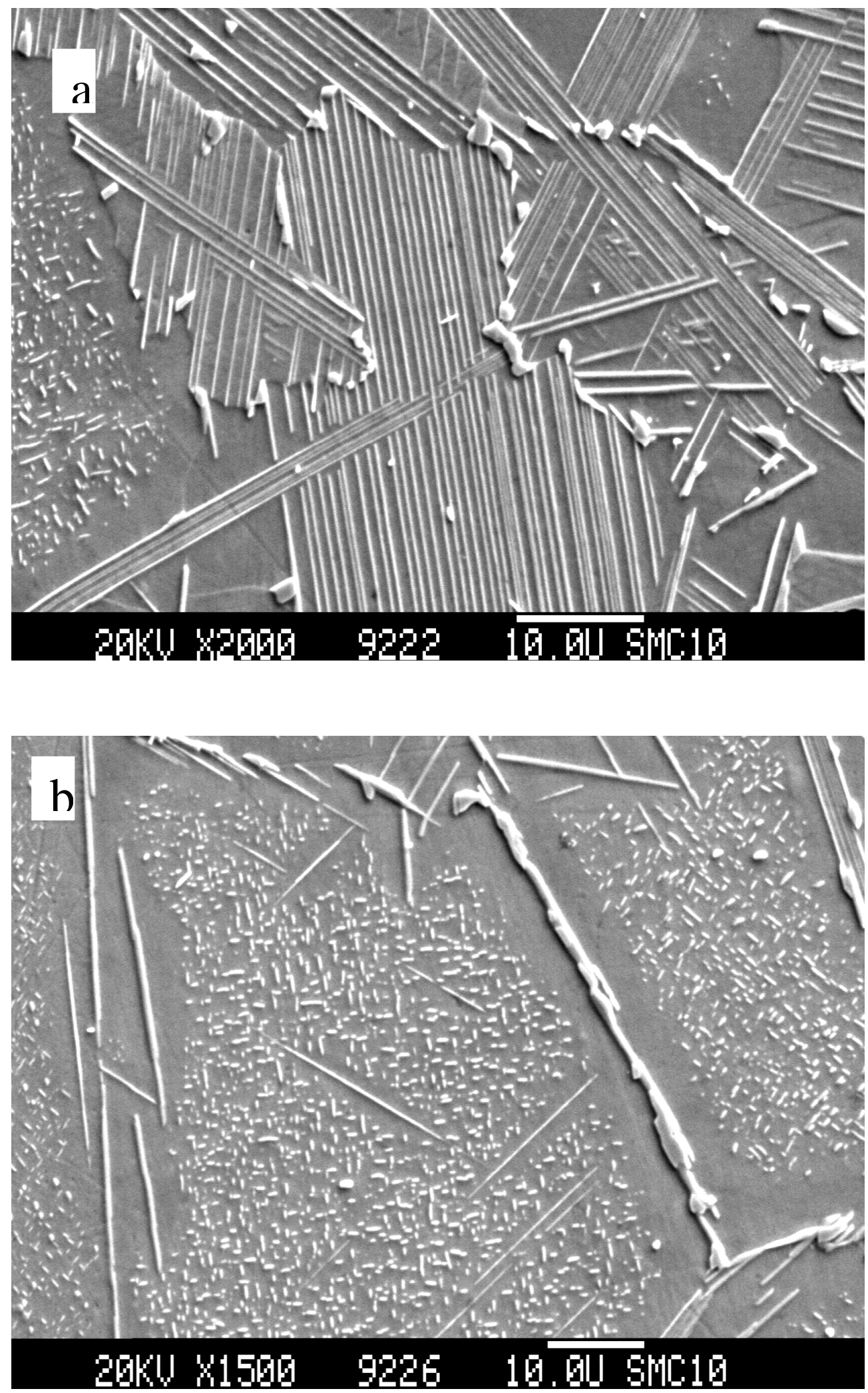
Figure 4. a) Shows colonies of inter- and intra-granular acicular $\eta$ particles, b) shows coarsened $\gamma^{\prime} / \gamma^{\prime \prime}$ precipitates and PFZ zone adjacent to grain boundaries.

Chemical composition and morphology of $\mathrm{Cr}+\mathrm{Ni}+\mathrm{Fe}$ rich particles is similar to $\mathrm{M}_{23} \mathrm{C}_{6}$ carbides [8].To identify $\mathrm{Cr}$-rich phase shown in figures $5 \mathrm{a}$ and $6 \mathrm{a}, \mathrm{XRD}$ analysis was carried out on the residue obtained by electrolytic dissolution of a sample exposed at $871^{\circ} \mathrm{C}$ for $100 \mathrm{~h}$. EDX analysis confirmed that the predominant phase in that residue was indeed Cr-rich type shown in figures 5a and 6a. X-ray diffraction analysis confirmed the presence of tetragonal-type $\sigma$ phase, figure 7. Lattice constants a and $\mathrm{c}$ of this phase were 8.9 and 4.6 angstrom respectively. Having established crystal structure and EDX pattern correlation of $\sigma$ phase, efforts were made to better define $\sigma$ phase field using SEM/EDX analysis of solid samples and extracted residues. SEM photograph and EDX pattern of electrolytically extracted $\eta$ phase is shown in figures $8 \mathrm{a}$ and $8 \mathrm{~b}$ respectively. This EDX pattern matched well with the $\eta$ phase reported in the literature [9]. EDX pattern from the matrix is shown for comparison in figure $8 \mathrm{c}$.

Chemical composition in atom percentage based on semi-quantitative EDX analysis of matrix, $\eta$, $\mathrm{M}_{23} \mathrm{C}_{6}$ carbide and $\sigma$ phase is shown in Table III. It should be mentioned that since chemical compositions of $\mathrm{M}_{23} \mathrm{C}_{6}$ carbide and $\sigma$ phase are comparable, SEM/EDX analysis of a solid sample may have difficulty in distinguishing small particles of these phases due to the limiting spatial resolution of an electron beam. Further, rather small particles of these phases are prone to dissolution during the electrolytic extraction process. Therefore, dedicated Scanning Transmission Electron Microscopy (STEM) analysis is required to better define $\sigma$ phase boundary.

\section{Microstructure at $927^{\circ} \mathrm{C}, 955^{\circ} \mathrm{C}$ and $982^{\circ} \mathrm{C}$}

Exposure of up to $4 \mathrm{~h}$ at $927^{\circ} \mathrm{C}$ did not reveal a presence of any detectable second phase. Eta precipitates were detected on $8 \mathrm{~h}$ and longer exposures, figure $9 \mathrm{a}$. These observations suggest that all $\gamma^{\prime} / \gamma^{\prime \prime}$, carbide and the $\sigma$ phase are in solution at $927^{\circ} \mathrm{C}$. Isothermal exposures at $955^{\circ} \mathrm{C}$ and $982^{\circ} \mathrm{C}$ showed an absence of $\eta$ and the other mentioned second phases. Microstructure of material exposed at $982^{\circ} \mathrm{C}$ for $25 \mathrm{~h}$ in figure $9 \mathrm{~b}$ show that the material is essentially devoid of any inter-granular precipitation.

\section{Time - Temperature - Transformation (TTT) Diagram}

All analytical data is presented in table IV. Based on this information, a TTT plot is presented in figure 11. Starting material annealed at $1038^{\circ} \mathrm{C}$ for $2 \mathrm{~h}$ had a grain size of ASTM \#2. It had essentially clean grain boundaries. The material did contain geometric intra-granular TiN particles shown later in the text. These are formed during the melt. Starting material also contained predominantly intra-granular, isolated spherical $\mathrm{NbC}$ carbide particles, which are primarily formed during thermo-mechanical processing. These $\mathrm{NbC}$ particles were earlier shown in figure 4b. All the analyzed TTT samples contained these two precipitates. Therefore, TiN and $\mathrm{NbC}$ are not shown in the TTT plot. It should be mentioned that the plot on $\gamma^{\prime} / \gamma^{\prime \prime}$ is primarily based on hardness testing. Stability of various phases is described below. 

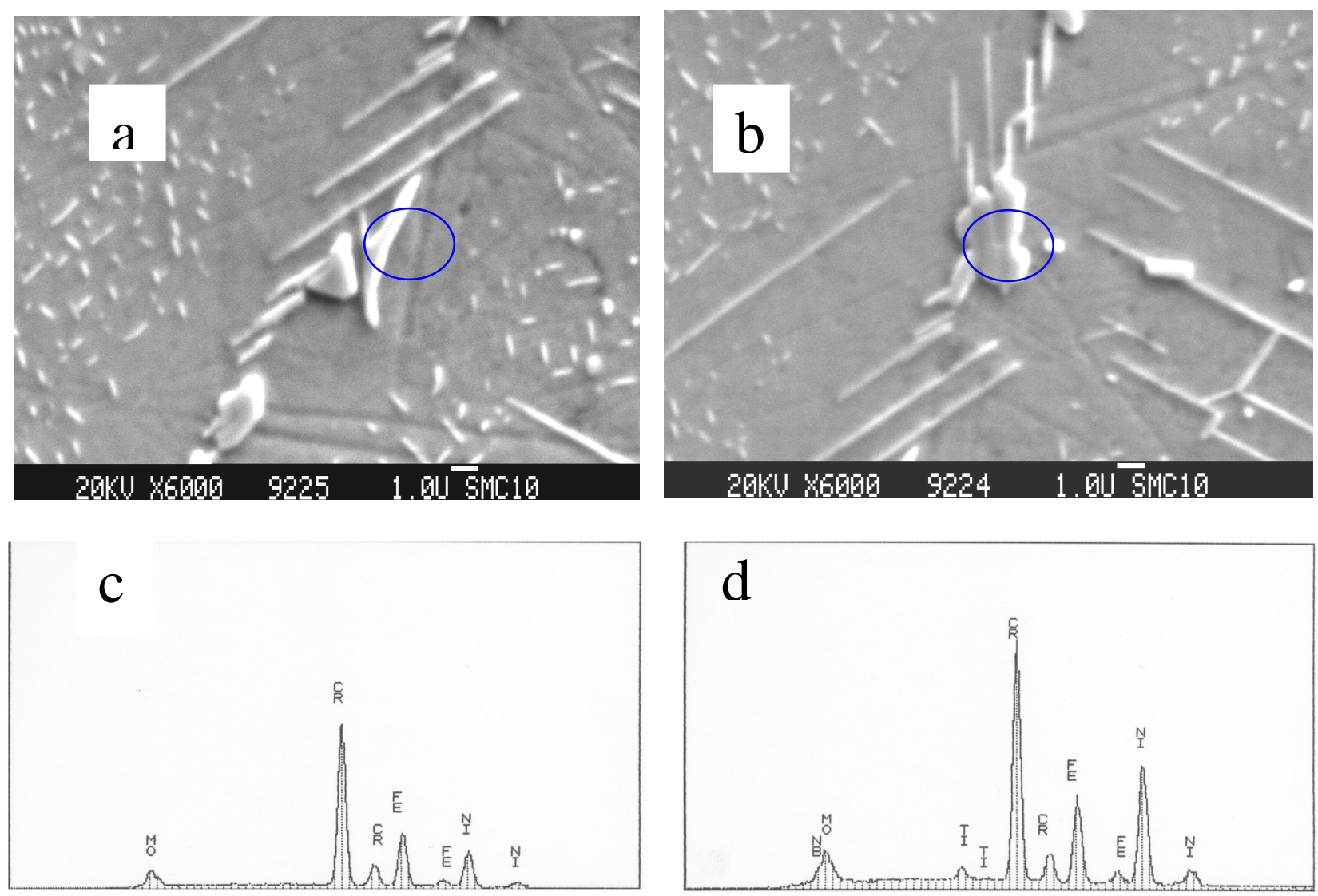

Figure 5a) shows circled elongated and figure 5b) shows circled irregular-roundish particle in the specimen exposed at $871^{\circ} \mathrm{C}$ for $100 \mathrm{~h}$. c) EDX pattern from the precipitate shown in figure 5a. d) EDX pattern from the particle shown in figure $5 \mathrm{~b}$.
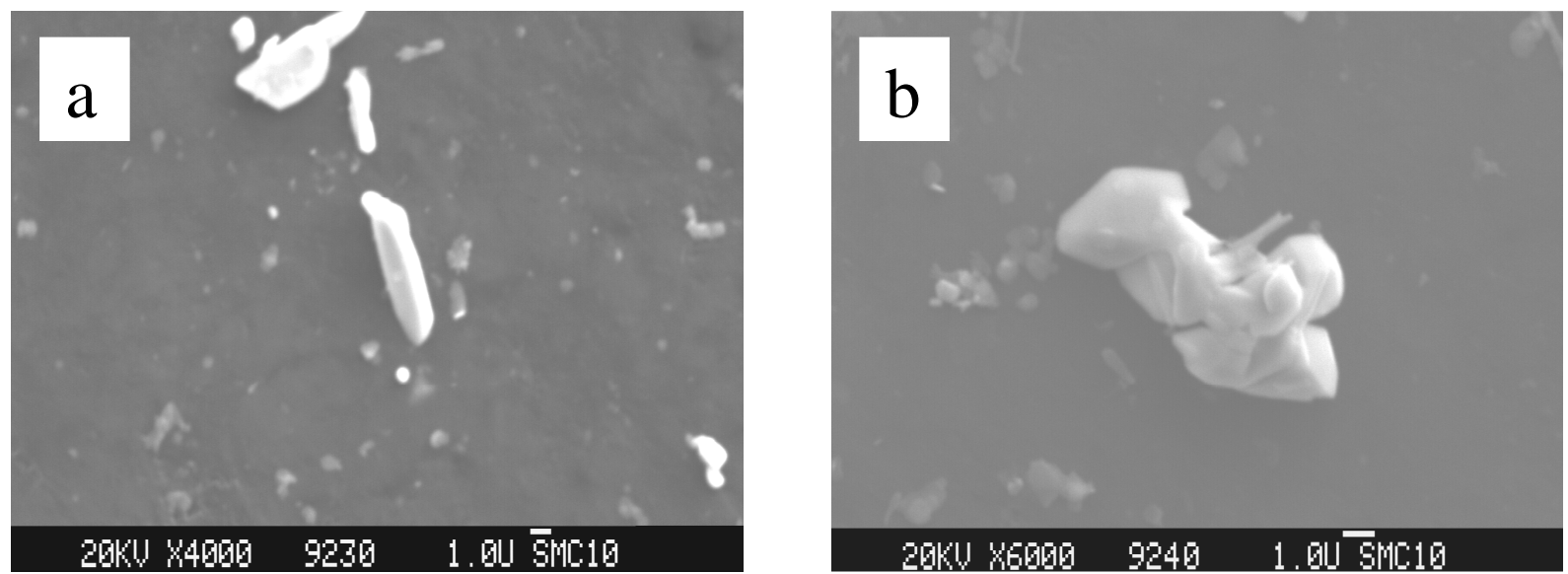

Figure 6. Particle from electrolytically extracted residue of the specimen exposed at $871^{\circ} \mathrm{C} / 100 \mathrm{~h}$. Figure a) center shows the elongated particle and figure b) shows irregular-roundish particle. 
EDX patterns of particles shown in $6 \mathrm{a}$ and $6 \mathrm{~b}$ matched with the patterns shown in figures $5 \mathrm{c}$ and $5 \mathrm{~d}$ respectively.

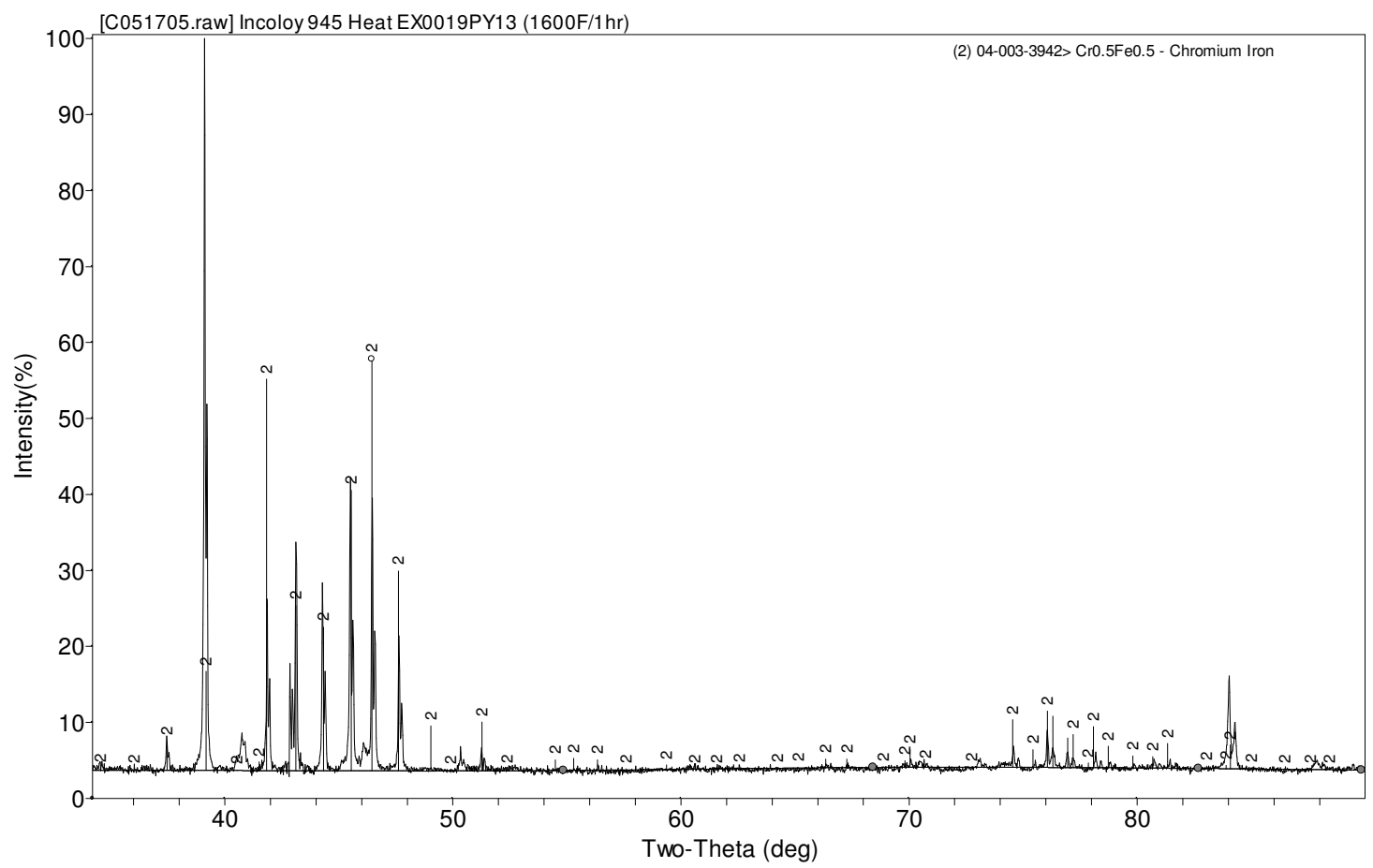

Figure 7. X-ray diffraction pattern of the extracted residue obtained from the sample exposed at $871^{\circ} \mathrm{C}$ for $100 \mathrm{hs}$. Line pattern of $\sigma$ phase is imposed on the experimental data.

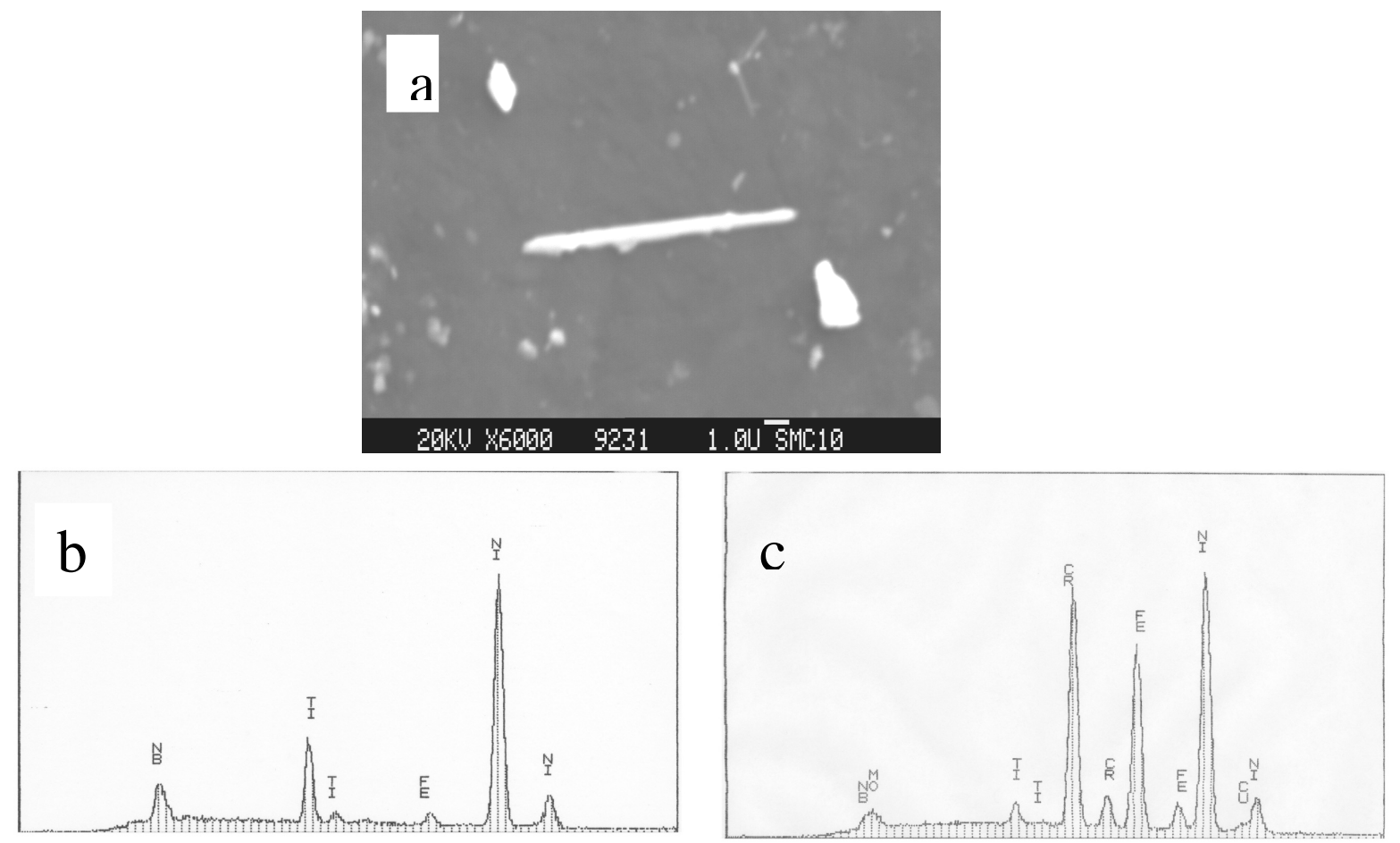


Figure 8. Electrolytically extracted residue of the specimen exposed at $871^{\circ} \mathrm{C} / 100 \mathrm{~h}$, a) $\eta$ particle; b) EDX pattern of $\eta$ particle and c) EDX of matrix. EDX pattern on eta shows $\mathrm{Ni}$ and $\mathrm{Ti}$ enrichment, some $\mathrm{Nb}$ is also picked up.

Table III. Shows semi-quantitative energy dispersive x-ray analysis of particles shown in Figures 8,9 and 10. It should be mentioned that these analysis are done without using elemental standards. $\mathrm{K}$ and $\mathrm{L}$ denote energy levels of the elements used for analysis.

\begin{tabular}{|c|c|c|c|c|c|c|}
\hline \multirow{2}{*}{ Phases } & \multicolumn{6}{|c|}{ Atom \% } \\
\cline { 2 - 7 } & $\mathrm{Cr}-\mathrm{K}$ & $\mathrm{Fe}-\mathrm{K}$ & $\mathrm{Ni}-\mathrm{K}$ & $\mathrm{Ti}-\mathrm{K}$ & Mo-L & Nb-L \\
\hline $\begin{array}{c}\text { Matrix ( wet chemical } \\
\text { analysis) }\end{array}$ & 23 & 23 & 46 & 1.8 & 2 & 2 \\
\hline Matrix (SEM/EDX) & 23 & 23 & $\mathbf{4 6}$ & 2.5 & 1.5 & 1.0 \\
\hline M23C6-carbide & $\mathbf{4 9}$ & 23 & 25 & - & 3 & - \\
\hline$\sigma$ & $\mathbf{3 8}$ & 18.5 & $\mathbf{3 6}$ & 2.5 & 3.5 & 1.5 \\
\hline$\eta$ & - & 3 & $\mathbf{7 8}$ & 13 & - & 6 \\
\hline
\end{tabular}
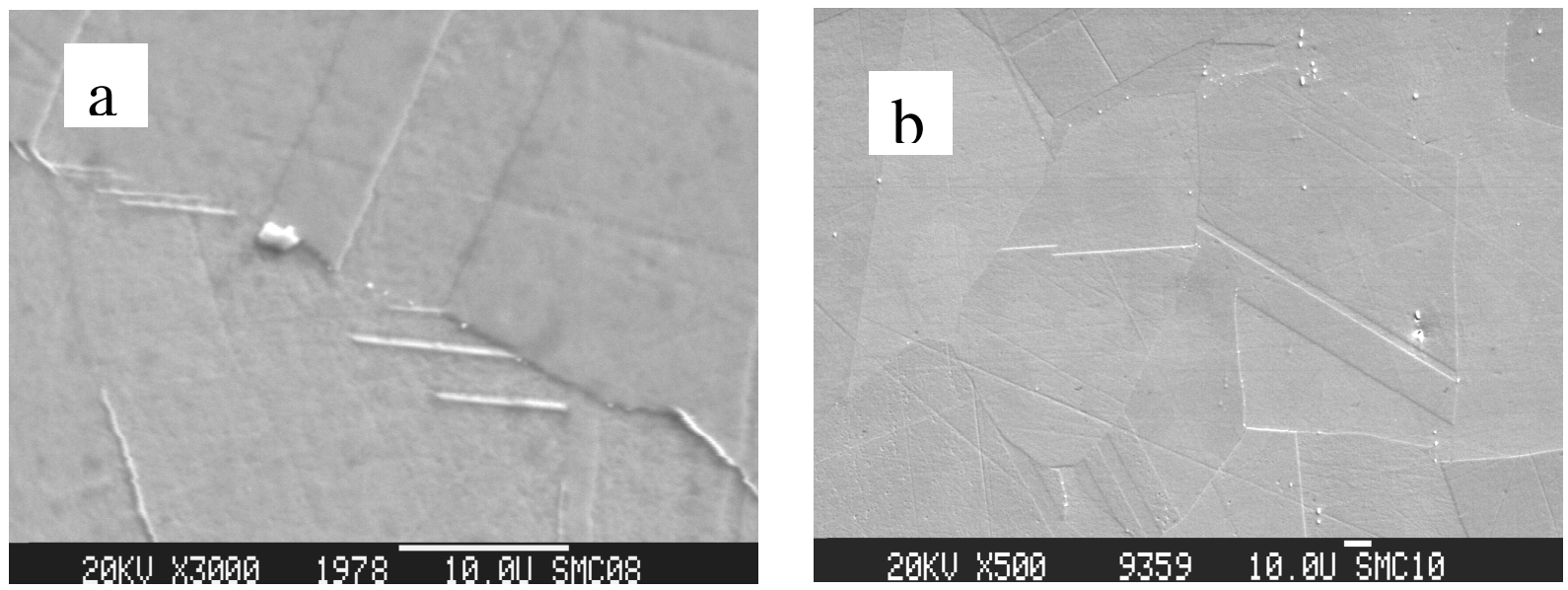

Figure 10. a) SEM photograph of a sample isothermally exposed at $927^{\circ} \mathrm{C}$ for $100 \mathrm{~h}$, coarse intergranular particle is NbC. b) SEM photograph of a sample exposed at $982^{\circ} \mathrm{C}$ for $25 \mathrm{~h}$. 
Table IV. Metallographic analysis of commercial alloy 945 annealed at $1038^{\circ} \mathrm{C}$ for $1 \mathrm{~h}$ water quenched and exposed at listed temperature for the specified intervals.

\begin{tabular}{|c|c|c|c|c|c|c|c|c|c|c|c|c|c|}
\hline \multirow{3}{*}{$649^{\circ} \mathrm{C}$} & \multirow{2}{*}{$0.25 \mathrm{~h}$} & \multirow{2}{*}{$0.5 \mathrm{~h}$} & \multirow{2}{*}{$1 \mathrm{~h}$} & \multicolumn{2}{|c|}{$4 \mathrm{~h}$} & \multicolumn{2}{|c|}{$8 \mathrm{~h}$} & \multicolumn{2}{|c|}{$25 \mathrm{~h}$} & \multicolumn{2}{|c|}{$50 \mathrm{~h}$} & \multicolumn{2}{|c|}{$100 \mathrm{~h}$} \\
\hline & & & & & & & & & & & & & \\
\hline & & & & & & & $\mathbf{a}$ & & a & b & $\mathbf{a}$ & b & $\mathbf{a}$ \\
\hline \multicolumn{14}{|l|}{$705^{\circ} \mathrm{C}$} \\
\hline & & & $\mathbf{a}$ & & & & $\mathbf{a}$ & b & $\mathbf{a}$ & b & $\mathbf{a}$ & b & $\mathbf{a}$ \\
\hline \multicolumn{14}{|l|}{$760^{\circ} \mathrm{C}$} \\
\hline & $\mathbf{a}$ & $\mathbf{a}$ & & & $\mathbf{a}$ & b & $\mathbf{a}$ & b & $\mathbf{a}$ & & & b & $\mathbf{a}$ \\
\hline & & & & & & & & & d & & & c & d \\
\hline \multicolumn{14}{|l|}{$816^{\circ} \mathrm{C}$} \\
\hline & $\mathbf{a}$ & $\mathbf{a}$ & & b & $\mathbf{a}$ & b & $\mathbf{a}$ & b & $\mathbf{a}$ & b & $\mathbf{a}$ & b & $\mathbf{a}$ \\
\hline & & & & & 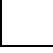 & c & & c & d & c & d & c & d \\
\hline \multicolumn{14}{|l|}{$871^{\circ} \mathrm{C}$} \\
\hline & $\mathbf{a}$ & $\mathbf{a}$ & & b & $\mathbf{a}$ & b & $\mathbf{a}$ & b & $\mathbf{a}$ & b & $\mathbf{a}$ & b & $\mathbf{a}$ \\
\hline & & & & c & & c & & c & d & c & d & c & d \\
\hline \multicolumn{14}{|l|}{$927^{\circ} \mathrm{C}$} \\
\hline & & & & & & & & & & & & & \\
\hline & 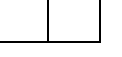 & & & & & c & & c & & c & & c & \\
\hline \multicolumn{14}{|l|}{$955^{\circ} \mathrm{C}$} \\
\hline $982^{\circ} \mathrm{C}$ & & & & & & & & & & & & & \\
\hline & & & & & & & & & & 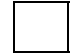 & & . & \\
\hline & & & & & & & & & & & & & \\
\hline
\end{tabular}


$\mathrm{a}=\gamma^{\prime} / \gamma^{\prime \prime}, \mathrm{b}=\mathrm{M}_{23} \mathrm{C}_{6}$ carbides, $\mathrm{c}=\eta, \mathrm{d}=\sigma$

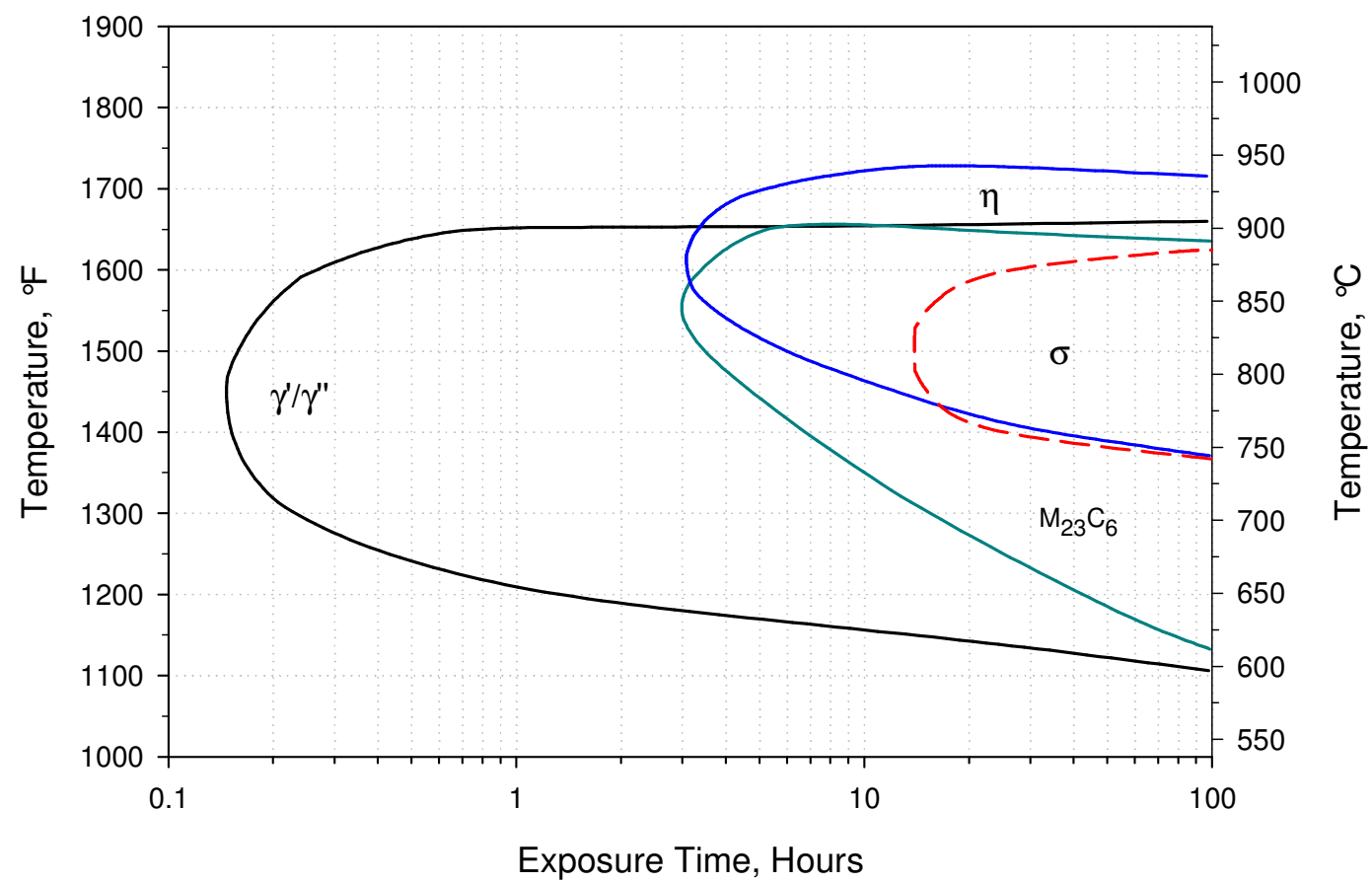

Figure 11. Time temperature transformation plot of alloy 945 annealed at $1038^{\circ} \mathrm{C}$ for $1 \mathrm{~h}$ water quenched and exposed at temperatures as shown. Dotted lines indicate ill defined phase boundary.

Gamma Prime and Gamma Double prime: These are submicron strengthening phases formed in intra-granular areas. Crystal structure and chemical composition of these phases are well documented [10-12]. Gamma prime has an ordered face centered cubic $\mathrm{LI}_{2}$-type crystal structure with a chemical formula of $\mathrm{Ni}_{3}$ (AlTi). It is spherical at low mismatch between $\gamma^{\prime}$ and $\gamma$ and it becomes cubic and plate like as mismatch is increased [12]. Gamma double prime has an ordered tetragonal $\mathrm{DO}_{22}$-type crystal structure. Both $\gamma^{\prime} / \gamma^{\prime \prime}$ have good solubility for $\mathrm{Co}, \mathrm{Cr}, \mathrm{Fe}, \mathrm{Nb}, \mathrm{Mo}$ and other elements [13]. The $\gamma^{\prime} / \gamma^{\prime \prime}$ phases transform to $\mathrm{Ni}_{3} \mathrm{X}$-type $\eta$ and $\delta$ phases in alloys containing sufficient amount of $\mathrm{Ti}$ and $\mathrm{Nb}$ [12]. In alloy 945, these phases are formed at temperatures as low as $600^{\circ} \mathrm{C}$. The strengthening effect is maximum in the temperature range of $649^{\circ} \mathrm{C}$ to $760^{\circ} \mathrm{C}$. Solvus temperature is in the range of $871^{\circ} \mathrm{C}$ to $827^{\circ} \mathrm{C}$.

$\underline{\mathrm{M}_{23}} \underline{\mathrm{C}}_{6}$-type Carbide: These Cr-rich precipitates have a complex face-centered-cubic crystal structure with lattice parameter of over 10 angstrom [14, 15]. In Ni-base alloys, these precipitates are found to contain $\mathrm{Ni}, \mathrm{Fe}, \mathrm{Mo}$ and some other elements from the matrix [8, 14]. In alloy 945 these are detected in the samples exposed for prolonged exposure of $50 \mathrm{~h}$ at $649^{\circ} \mathrm{C}$ and $25 \mathrm{~h}$ at 
$704^{\circ} \mathrm{C}$. Precipitation time is shorter in the temperature range of $760^{\circ} \mathrm{C}$ to $871^{\circ} \mathrm{C}$. Solvus temperature is in the range of $871{ }^{\circ} \mathrm{C}$ to $927^{\circ} \mathrm{C}$.

Sigma Phase: Wallwork and Croll [16] have reviewed $\sigma$ phase in great details. It has a tetragonal $\mathrm{D} 8$ b type crystal structure. There are at least 45 binary and ternary systems known where $\sigma$ is reported. Presence of certain phases including $\mathrm{M}_{23} \mathrm{C}_{6}$ carbide can induce $\sigma$ phase formation and $\mathrm{Si}$ is known to stabilize it. The favorable role of $\mathrm{Ni}$ in suppressing $\sigma$ formation is well known. In alloy $945, \sigma$ phase was detected in the temperature range of $760^{\circ} \mathrm{C}$ to $871^{\circ} \mathrm{C}$. Sovlus temperature is in the range of $871{ }^{\circ} \mathrm{C}$ to $927^{\circ} \mathrm{C}$. Due to similar chemical compositions of sigma and $\mathrm{M}_{23} \mathrm{C}_{6}$ and limited spatial resolution of SEM/EDX, dedicated STEM analysis is required to better define sigma phase boundaries.

Eta Phase: Eta has a hexagonal $\mathrm{DO}_{24}$ type structure $[9,16]$. In $\gamma^{\prime} / \gamma^{\prime \prime}$ strengthened alloys, $\eta$ or $\delta$, a tetragonal $\mathrm{DO}_{\mathrm{a}}$ - type structure, forms on prolonged exposure or at higher temperature exposures. Both these phases have acicular morphology. Although based on its chemical composition, it is possible for both of these to form, only $\eta$ phase was detected in alloy 945 . This is consistent with findings reported in alloy 706, which has similar $\mathrm{Nb}$, Ti and Al contents [9]. In alloy $945, \eta$ phase was detected on prolonged exposure at $760^{\circ} \mathrm{C}$. The aspect ratio was found to increase as exposure temperature is increased. Further, both inter- and intra-granular $\eta$ phase were detected in the temperature range of $827^{\circ} \mathrm{C}$ to $871^{\circ} \mathrm{C}$. Solvus temperature of $\eta$ phase was in the range of $927^{\circ} \mathrm{C}$ to $955^{\circ} \mathrm{C}$.

\section{Commercial Heat Treated Microstructure and Mechanical Properties}

To obtain desired properties of alloy 945, the material is annealed at $1038^{\circ} \mathrm{C}$ for time commensurate with thickness. This is followed by 2-step age hardening: expose at $704^{\circ} \mathrm{C}$ for $8 \mathrm{~h}$, furnace cool to $621^{\circ} \mathrm{C}$, hold at $621^{\circ} \mathrm{C}$ for 8 hours and air cool. Table V shows room temperature tensile and $-59^{\circ} \mathrm{C}$ impact properties. Material was tested for tensile properties in the longitudinal orientation and for impact properties in the transverse orientation. This is required for O\&G API specifications [6]. Figure 12 shows optical microstructure of annealed + aged materials. Grain boundaries are essentially devoid of any precipitation. Figure 13 shows TEM photograph and selected area diffraction pattern revealing presence of strengthening submicron $\gamma^{\prime} / \gamma^{\prime \prime}$ precipitates.

Table V. Mechanical properties of alloy 945. YS, UTS, El, and RA stands for yield strength, tensile strength, elongation and reduction of area. The impact toughness was tested at $-59^{\circ} \mathrm{C}$ in transverse orientation.

\begin{tabular}{|c|c|c|c|c|c|c|c|}
\hline $\begin{array}{c}\text { Rod Size, } \\
\text { mm }\end{array}$ & YS, MPa & UTS, MPa & $\%$ El & $\%$ RA & $\begin{array}{c}\text { Impact, } \\
\text { Joules }\end{array}$ & $\begin{array}{c}\text { Hardness, } \\
\text { Rc }\end{array}$ & $\begin{array}{c}\text { Grain Size, } \\
\text { ASTM \# }\end{array}$ \\
\hline \hline 89 & 939.8 & 1201.1 & 24.9 & 39.5 & 77 & 40 & 2 \\
& 934.3 & 1185.9 & 25.5 & 40.5 & 79 & 43 & 2 \\
\hline
\end{tabular}




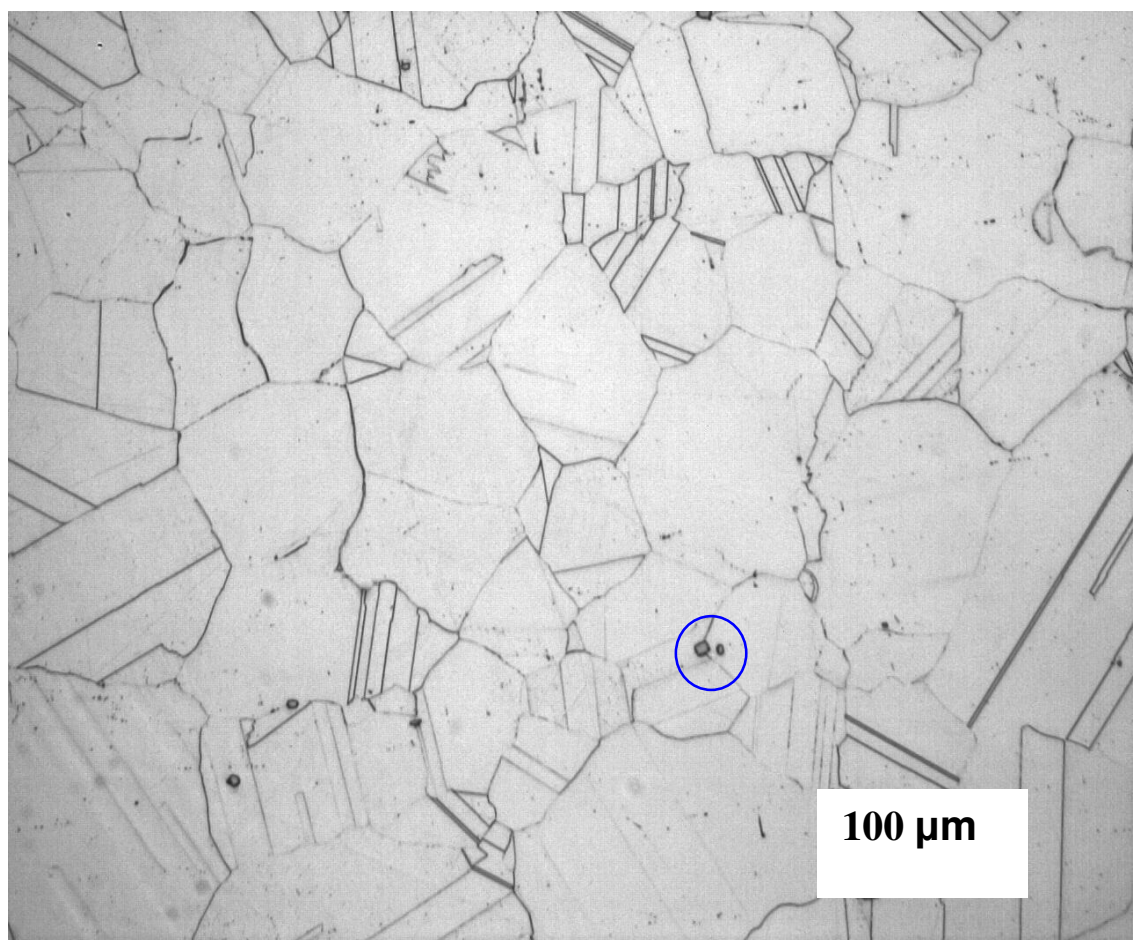

Figure 12. Optical photographs of annealed + aged alloy 945 at 100X. Material shows essentially clean grain boundaries and isolated geometric TiN particles shown in a cicle. These precipitates are formed from the melt.

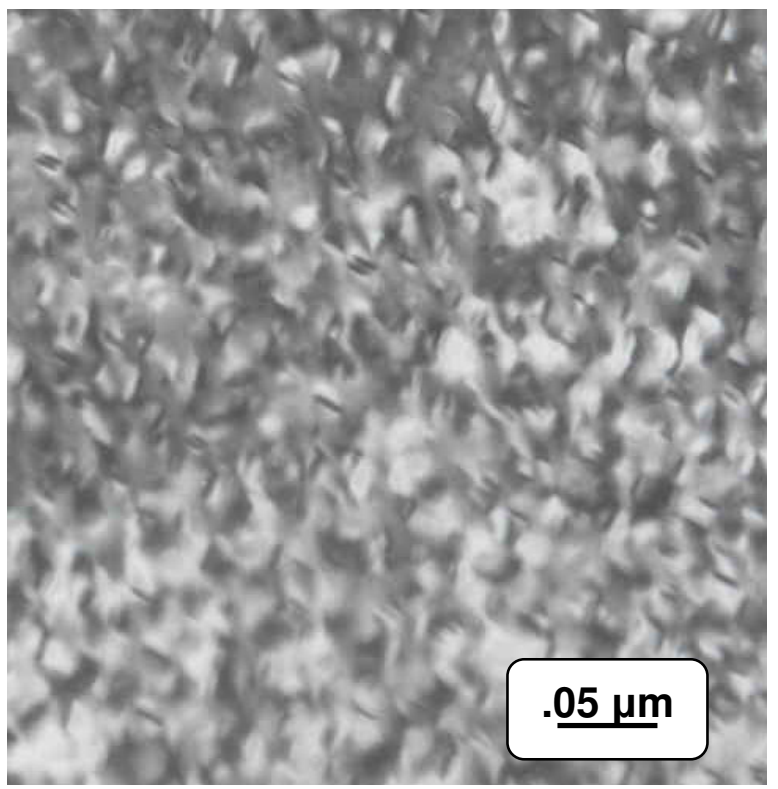


Figure 13. TEM photograph of annealed + aged alloy 945. The left shows $\gamma^{\prime} / \gamma^{\prime \prime}$ distribution and the right shows selected area diffraction pattern of these phases in [001] zone axis.

\section{Conclusions and Summary}

Alloy 945 is a Ni-base superalloy developed specifically for O\&G applications. It is precipitation strengthened by submicron $\gamma^{\prime} \mathrm{Ni}_{3}(\mathrm{AlTiNb}\}$ and $\gamma^{\prime \prime} \mathrm{Ni}_{3}(\mathrm{NbAlTi}$ ) precipitates. Strengthening capability is maximum in the temperature range of $649^{\circ} \mathrm{C}$ to $760^{\circ} \mathrm{C}$. Higher temperature exposure results in the formation of $\mathrm{Ni}_{3}$ Ti type $\eta$ phase and $\mathrm{M}_{23} \mathrm{C}_{6}$ carbides. Prolonged exposure at higher temperature can result in the formation of $\sigma$ phase.

It should be emphasized that differences in chemical composition and local chemical inhomogeneity can shift the TTT curve. Further, different melt / re-melt and thermo-chemical processing can alter the volume fraction and size distribution of $\mathrm{MC}$-type $\mathrm{Nb}$ and $\mathrm{Ti}$ containing nitrides, carbides and carbonitrides. This can shift the TTT curve or even result in formation of phases not reported in this work. Therefore, the TTT plot presented in this paper is specific to the reported chemical composition, size, and processing.

\section{Acknowledgements}

Author would like to thank Dr. Shailesh Patel, Vice President Technology and Dr. John deBarbadillo, Manager Process and Product Development for their encouragement and guidance on carrying out this research. Special thanks to Mr. Frank Veltry for his assistance in doing analytical work.

\section{References}

1. S. K Mannan and S. J. Patel, "A New High Strength Corrosion Resistant Alloy for Oil and Gas Application, Corrosion 2008, NACE International, Paper No. 8084.

2. S. K Mannan, "Alloy 945 and its Derivatives - Higher Strength Products for Oil and Gas, Corrosion 2010, NACE International, Paper No 10310.

3. S. K Mannan and S. J. Patel, "A New Ni-base Superalloy for Oil and Gas Applications", Superalloys 2008, Edited by Roger C. Reed et al, TMS, 2008, 31-39.

4. S. K. Mannan, E L. Hibner and B. Puckett, "Physical Metallurgy of Alloys 718, 725, 725HS and 925 for Service in Aggressive Corrosive Environments, Corrosion 2003, NACE International, Paper No 3129.

5. T. Cassagne et al, "Understanding Filed Failures of Alloy 718 Forging Materials in HP/HT Wells, EuroCorr, 2008.

6. Nickel Base Alloy 718 (UNS N07718) for Oil and gas Production Equipments, API Standard 6A 718, Second Edition, December 2009.

7. D. B. Williams, Practical Analytical Electron Microscopy in Material Science, Philips Electronics Instruments, Inc, New Jersey, 1987. 
8. Unpublished work, Special Metals Corporation, Huntington, WV, USA.

9. K. A. Heck, "The Time-Temperature-Transformation Behavior of Alloy 706", Superalloys 718, 625, 706 and Various Derivatives, Edited by E. A. Loria, Warrendale, PA: TMS, 1994, 393404.

10. D. F. Paulonis, J. M. Oblak and Duvall, "Precipitation in Nickel - Base Alloy 718" Transactions of ASM, Vol. 62, 1969, 611-622.

11. S. T. Wlodek, "The Stability of Superalloys", Long Term Stability of High Temperature Materials, Edited by G. E. Fuchs et al, TMS, 1999.

12. C. T. Sims, N. S. Stoloff, and W. C. Hagel, Superalloys II, John Eiley \& Sons, New York, 1987.

13. M. G. Burke and M. K Miller, "Precipitation in Alloy 718: A combined AEM and APFIM Investigation", Superalloys 718, 625, 706 and Derivatives, Edited by E. A. Loria, Warrendale, PA: TMS, 2000, 449-458.

14. M. Raghavan et al, "Carbides in Ni-Cr-Mo Systems", Scripta Metallorgica, Vol 17, 1983, 1189-1194.

15. M. Gao and R. P. Wei, "Precipitation of Inter-granular $\mathrm{M}_{23} \mathrm{C}_{6}$ carbides in a Nickel Alloy: Morphology and Crystallographic Feature" Scripta Metallurgica, Vol. 30, No 8, 1994, 10091014.

16. G. Wallwork and J. Croll, "A Review of the Strengthening Mechanisms in Iron and Nickel Based Fe-Ni-Cr Alloys used at High Temperatures", Review on High Temperature Materials, Edited by J. B. Newkirk, Vol. III, No 2, 1976 